\title{
Laws for Sale: Evidence from Russia ${ }^{\nabla}$
}

\author{
Irina Slinko, Evgeny Yakovlev, and Ekaterina Zhuravskaya ${ }^{ \pm}$
}

Key words: Regulatory capture, institutional subversion, Russia, redistribution, special interest politics

JEL classification: P26, P27, D71, D72

Send correspondence to:

Ekaterina Zhuravskaya, CEFIR, Nakhimovsky prospect, 47, office 1720, 117418, Moscow, Russia; phone: +7(095)1055002; fax:+7(095)1055003; e-mail: EZhuravskaya@CEFIR.ru 


\begin{abstract}
:
How does regulatory capture affect growth? We construct measures of the political power of firms and regional regulatory capture using micro-level data on the preferential treatment of firms through regional laws and regulations in Russia during the period 1992-2000. Using these measures, we find that: 1) politically powerful firms perform better on average; 2) a high level of regulatory capture hurts the performance of firms that have no political connections and boosts the performance of politically connected firms; 3) capture adversely affects small business growth and the tax capacity of the state; 4) there is no evidence that capture affects aggregate growth.
\end{abstract}


“...oligarchy [...] throws a close network of dependence relationships over all the economic and political institutions of present-day bourgeois society without exception...”

Vladimir Lenin

(“Imperialism: The Highest Stage of Capitalism,” 1916)

\section{Introduction}

At least since Olson (1965) and Stigler (1971), economists have recognized the role of special interests in shaping institutions, the phenomenon known as "state capture" or "institutional subversion.” Throughout history and all across the world firms seek to distort the legal framework, justice, rules, and regulations by influencing politicians and bureaucrats. The ability of governments to withstand influence varies depending on the local political and economic environment, e.g., on industrial concentration, inequality, electoral competition, electoral uncertainty, the awareness of voters, the cohesiveness of interest groups, and political centralization. ${ }^{1}$

What are the effects of having political power concentrated in the hands of a few firms? On the one hand, as argued by Olson (1982), the domination of special interests can be detrimental to economic growth because rent-seeking diverts resources from productive activities and slows down

innovation. $^{2}$ On the other hand, populist governments may harm economic growth more than governments influenced by special interests because of excessively high rates of taxation of productive capital under the former (Alesina and Rodrik, 1994). While the theory gives an ambiguous answer, empirically, the question is not settled.

This paper evaluates the effect of the domination of special interests on the performance of firms that do and do not have political power, on aggregate growth, on small business growth, and on taxation. We use a unique micro-level dataset on Russian regional laws and regulations that treat specific firms preferentially to construct direct measures of firms' political power and the extent of 
regional capture. This is a panel that contains information on special favors granted by regional legislators and regulators to a comprehensive list of the largest firms in each Russian region between 1992 and 2000. We take the share of favorable laws and regulations received by a firm as a proxy for its political power, and the concentration of favors among firms in a region as a measure of capture of legislature and regulatory agencies. Most previous empirical studies of the effects of regulatory capture, particularly in developing and transition countries, are based on cross-section evidence from subjective survey data. In contrast, this paper utilizes objective panel data on the outcomes of successful lobbying. ${ }^{3}$

Transition countries provide an ideal experiment for studying private interests' interference in formation of state institutions. Privatization gave rise to substantial wealth inequality in these countries, while communism bequeathed weak legal and political institutions. The fragility of democratic mechanisms and the low accountability of the state to the public made governments in transition easily susceptible to capture. As a result, a newly created group of rich and politically powerful was able to shape institution-building processes (Glaeser, Scheinkman, and Shleifer, 2003; Guriev and Rachinsky, 2004; Sonin, 2003a and 2003b; Hellman, 1998; and Ericson, 2000). Russia provides a particularly good case to study the consequences of capture: First, the domination of big firms makes it easy to identify potential captors. Second, in the early 1990s Russia underwent substantial economic and political decentralization in which regions gained autonomy in regulations and legislation (Shleifer and Treisman, 2000 and OECD, 2000). Decentralization resulted in high variation in regional political institutions and their vulnerability to special interests, which allows comparative analysis. And third, in contrast to most crony capitalist countries, in Russia all regional laws and regulations are in the public domain, which is why we were able to collect the data. (In contrast, in Uzbekistan legislation that gives favorable treatment to specific firms is a state secret). 
We find that private benefits allow captors to grow faster than their counterparts and that these gains to captors increase with an increase in concentration of political power in their hands. Capture of laws and regulations has adverse effects on performance and investment of firms that have no political influence, on small business growth, and on tax collection. Yet, we do not find evidence that aggregate growth has been significantly affected by the extent of regulatory capture. ${ }^{4}$

The paper proceeds as follows. Section 2 presents hypotheses. Data and measurement are described in section 3. We present results in section 4. Conclusions follow in section 5.

\section{Hypotheses}

In this section, we briefly state theoretical predictions about the effects of concentration of political power in the hands of a few firms on the growth of these firms, growth of firms that do not have political power, aggregate growth, small business development, and regional tax collection.

Firm performance: First, we compare the performance of firms with and without political connections. Firms that are rewarded with favored treatment by bureaucrats and politicians should perform better and invest more because they enjoy protection against competition. Since political power allows firms to subvert contract enforcement institutions and, therefore, escape punishment for breaching contracts, politically influential firms should have higher bargaining power vis-à-vis workers and suppliers. Thus, we expect the outcomes of firms' bargaining with employees and contractors to differ for firms with and without political power: the effective costs of inputs should be smaller for influential firms. There is much anecdotal evidence that enterprises with direct ties to regional authorities have an easier time protecting themselves in regional courts from the lawsuits of suppliers and creditors. ${ }^{5}$ In addition, the tax arrears of politically influential firms should be higher because they lobby for less strict tax enforcement.

Second, we are interested in how the concentration of political power affects firms. We expect a higher concentration of political power to bring greater benefits to the firms that are 
included in the circle of the politically powerful and greater costs to the firms that are excluded from this circle because of lower competition for capture and smaller dissipation of rents among the captors.

Small business growth: Large firms in transition economies may be interested in small business growth because they cannot shed excess labor for political reasons unless there are small businesses to absorb it. ${ }^{6}$ Small business growth may also be against the interests of large firms when they compete with small firms for government resources (Gehlbach, 2003) and scarce skilled labor (Friebel and Guriev, 2002), or in product markets (Lewis, 1945). Depending on which of these two effects dominates, politically powerful firms will lobby regional authorities for creating either a predatory or benign regulatory environment for small business. The reason why large firms may find this kind of lobbying worthwhile is that Russia's regional authorities have considerable discretion over regulating small business: they can directly influence entry costs by altering the rules of registration, certification, and licensing, and operating costs with the help of inspections and regional property leases (see Zhuravskaya, 2000 and CEFIR Monitoring Report, 2002). In addition, if large enterprises divert government spending, there are fewer resources left for investing in infrastructure for small business and the salaries of bureaucrats who see preying on small business as an alternative source of income (Gehlbach, 2003).

Aggregate growth: Capture should result in lower investment and growth in discriminated firms and higher investment and growth in politically influential firms. In theory, the aggregate effect is ambiguous. Olson (1982) used case studies of post-war Europe and India, and Japan in the $20^{\text {th }}$ century, to argue that special interests hurt aggregate growth. We test for this effect in our data.

Tax collection and arrears: Tax collections from politically influential firms are expected to decrease with an increase in the level of capture because vested interests lobby for tax breaks. Under the conditions of an underdeveloped small and medium-size business sector and a sizable unofficial 
economy (e.g., Russia in the 1990s), aggregate tax collections should be affected by capture because large enterprises with political influence usually happen to be the primary contributors to regional budgets. Federal tax arrears may increase with capture because regional authorities can protect firms from federal tax collectors by exercising political control over local branches of federal courts and tax collection agencies. ${ }^{7}$

\section{Data}

To measure capture and firms' political power, we constructed a database of regional laws and regulations which treat selected large firms in these regions preferentially. For feasibility reasons, we set boundaries to our analysis of Russian regional legislation, limiting ourselves to the largest firms in each region because political influence is most likely concentrated in the hands of the largest firms. We started with a list of firms which at least once during 1992 - 2000 were among the five firms with the largest sales in each region. ${ }^{8}$ The list contained 978 firms - up to the 20 largest firms in each of 73 regions (autonomous okrugs excluded). We searched the comprehensive database of Russia's regional legislation "Consultant Plus" (www.consultant.ru/Software/Systems/RegLaw) for any preferential treatment of each of these firms for each year between 1992 and 2000. We deemed an enterprise to be treated preferentially if it received any of the following benefits: tax breaks, investment credits, subsidies, subsidized loans and loans with a regional budget guarantee, official delays in tax payments, subsidized licensing, free grants of state property, or a special "open economic zone” status for their territory. The most common preferential treatment is a tax break ( $46 \%$ of the total number of preferential treatments); the second most common is a subsidized loan from the budget or a direct government subsidy (26\%); the next largest group of preferential treatments is subsidized energy prices (5\%).

Typical examples of preferential treatment legislation are as follows. In 1998, the Volgograd regional legislature adopted the law "On a special economic zone on the territory of Volgograd 
Tractor Plant (VTP).” The law relieves all firms of paying regional and local taxes for the period of ten years if these firms operate on the territory of VTP and at least $30 \%$ of their assets are in VTP's ownership. In Adygeya Republic in 1999 a law was enacted "On preferential tax treatment of the meat-packing plant Li-Chet-Nekul.” The law grants this plant a property tax break for a period of two years. The budget law of Kamchatskaya Oblast of 2001 contained a special budgetary item called "support of fishing industries." It postulated that only one firm, named Akros, receive a large sum of money. There were many fishing firms in Kamchatskaya Oblast at that time, but no other firm was mentioned in the budget law.

We produced the number of regional laws and regulations that grant distinct preferential treatments to each firm in the sample each year. To check the quality of these data, we correlate firms’ preferential treatments with budgetary subsidies reported in firms' balance sheets and find a strong significant correlation despite the fact that direct subsidies are not the most common type of preferential treatments. Between 1992 and 2000, 41\% of firms in the sample received at least one preferential treatment; $23 \%$ of firms received at least two preferential treatments; and $21 \%$ of firms received preferential treatments for at least two years. During 1996 - 2000, each year on average $17 \%$ of firms were treated preferentially and $18 \%$ of firms received preferential treatments for at least two years. Preferential treatments are persistent: If a firm receives preferential treatments in any particular year, there is an over $60 \%$ chance that it also receives preferential treatments in the subsequent or the previous year. ${ }^{9}$

An important question is how many preferential treatments are given to firms outside our sample of firms. In five regions, we searched legislation for the fifty largest firms and did not find any preferential treatment granted to firms outside our original sample. ${ }^{10}$

Using the preferential treatment data, we constructed measures of regional regulatory capture and firms' political power. Regional capture each year is measured by the concentration 
(Herfindahl-Hirschman Index) of preferential treatments for the five firms with the largest number of preferential treatments. We focus on the concentration rather than the number of preferential treatments because we are interested in the effect of the concentration of political power in hands of few firms. The total number of preferential treatments in the region may just reflect the general level of paternalism of the regional governments: If a regional government gives preferential treatments to all firms, none is treated preferentially. We use the total number of preferential treatments as a control in all regressions. We use information only for the five largest recipients of preferential treatments in each region to make the measures comparable across regions. (As a rule, fewer than six firms receive preferential treatments over the course of one year in any given region.) The political power of each firm each year is measured by the share of this firm's preferential treatments in the total number of preferential treatments given to the five firms with the largest number of preferential treatments in the region. Again, to control for paternalism, we focus on the relative rather than raw number of preferential treatments.

Table A1 in the appendix illustrates the construction of preferential treatment concentration and the regional number of preferential treatments for three regions: a typical region (Omsk oblast), the most captured region (Chelyabinsk oblast), and the most non-captured region (Arkhangelsk oblast). ${ }^{11}$ Table 1 presents summary statistics and Table A2 presents the average index of regional capture for $1995-2000 .^{12}$

To supplement the preferential treatments data, we use the following panel data: Financial and other statistical data on enterprises come from the Russian Enterprise Registry Longitudinal Dataset (RERLD) and ALBA datasets. RERLD covers the basic financial statistics for large and medium-size firms in Russia, with data spanning the period from 1992 to 2000; Brown and Earle (2000) provide a detailed description of the database. ALBA contains the balance sheets of large and medium-size firms between 1996 and 1999. Regional budgetary data for 1996 - 2000 come 
from the Ministry of Finance (www.minfin.ru). Other region-level statistics come from Goskomstat, Russia’s official statistical agency (http://www.gks.ru/catalog/default.asp). For the most part, Goskomstat's regional series are available for 1996-2000, but some (e.g., retail turnover) start in 1992.

\section{Results}

Performance and investment of firms with and without political power

First, we investigate whether firms with political power grow faster, perform better, and have superior outcomes in bargaining with suppliers and employees compared to similar firms that have no political power. We measure performance by growth in sales, employment, fixed capital, labor productivity, and profitability. Outcomes of firms’ bargaining with suppliers and workers are measured by arrears to suppliers and wage arrears, respectively. We look at arrears because large firms in Russia reduce costs primarily by running arrears rather than negotiating input prices. In addition, we look at the effect of political power on tax arrears. As discussed in the hypotheses section, we expect firms with political power to have superior performance, but maintain higher wage, trade, and tax arrears.

We estimate the long-run relationship between performance and political power of firms using between-effects regressions (i.e., regressions of over-time sample averages), controlling for initial performance and region-specific fixed effects:

$\overline{y_{f}}=\alpha_{1} \overline{P T \_ \text {share }_{f}}+\alpha_{2} y_{f_{t_{0}}}+\alpha_{3}$ controls $_{f}+r_{f}+\varepsilon_{f}$.

and the short run relationship using firm-specific fixed-effects regressions:

$y_{f t}=\alpha_{1} P T_{-}$share $_{f t}+\alpha_{2} P T_{-}$concentr $_{f t-1}+\alpha_{3} P T_{-}$number $_{f t-1}+\alpha_{4}$ controls $_{f t}+\phi_{f}+\varepsilon_{f t}$

where $y$ stands for log of an indicator of firms' performance or arrears; the subscripts $f$ and $t$ identify firms and years; and the subscript $t_{0}$ denotes the initial year. ${ }^{13} P T$ share is the firm’s share 
of preferential treatments. $P T_{\_}$concentr is the preferential treatment concentration and $P T \_n u m b e r$ is the total number of preferential treatments in the region; both are calculated for the five firmsrecipients of the largest number of preferential treatments. $\phi_{f}$ and $r_{f}$ are firm and region fixed effects, respectively. Upper bars denote average values of variables across all years excluding the initial year. We are interested in the coefficient of the share of preferential treatments (our measure of a firm's political power). ${ }^{14}$

We run both basic OLS and IV regressions. A potential source of endogeneity in these regressions is the quite plausible dependence of the firms' shares of preferential treatments on their performance. We use the relative initial size of the firm in between-effects regressions and the twoyear lag of the relative size in fixed-effects regressions as instruments for preferential treatment shares. The initial size of a firm relative to other firms in the region is the best predictor of the likelihood of receiving preferential treatments in the future. Moreover, being a legacy of a central planning system, initial size is exogenous. Again, to have comparability across regions, size is calculated relative to the five largest firms in the region. ${ }^{15}$

Since a firm's benefit from political connections depends on the concentration of political power among firms (Hellman, Jones, and Kaufmann, 2003), we control for the scale of regional capture. In the fixed-effects regressions, we include the lagged preferential treatment concentration and the lagged total number of regional preferential treatments to control for capture. ${ }^{16}$ In betweeneffects regressions, region fixed effects account for all regional differences. National market share is a control for market power in regressions for productivity, profitability, investment, and arrears (this is an important control because preferential treatments are given to large firms). In fixed-effects regressions, we use lagged values, and in between-effects regressions initial values, of this variable. In between-effects regressions, the state enterprise dummy accounts for the difference in performance of state and private firms and industry dummies control for industry-level 
performance. We also add dummies for firms that drop out and appear in the enterprise registry between 1996 and 2000, since the particular stage of these firms' life cycle may affect performance. Eliminating these firms from the sample does not affect the results. Finally, we allow error terms to be clustered within regions. Since the vast majority of firms in our sample are non-traded, we have no data to control for firms' investment opportunities (e.g., Tobin’s Q).

The results are consistent with our hypotheses. There is a strong robust effect of political power on firm performance: firms that enjoy a disproportionate number of preferential treatments exhibit significantly faster growth in profitability, sales, employment, and fixed capital. Despite these performance gains, politically influential firms accumulate tax, wage, and trade arrears significantly faster than their not-politically-connected counterparts. OLS and IV regressions produce similar results, with an increase in the magnitude and significance levels of the coefficients in the IV regressions. Henceforth, as a baseline, we report IV regression results because, in our view, both endogeneity and measurement error are important in this context.

We illustrate the basic cross-section regularities in the data in Figure 1. The first chart in the figure reports the means of performance indicators along with their confidence intervals for the two equal-sized sub-samples. Firms are sorted into the subsamples on the basis of their average preferential treatment share. Firms with the highest shares of preferential treatments have better performance and higher arrears than firms with the lowest shares of preferential treatments. Table 2 presents results of the estimation of equation (1) using instrumental variables. The results confirm the basic correlations: A ten percent increase in the average share of preferential treatments over eight years (from a mean value of 0.15 ; $\mathrm{SD}=0.09$ ) leads to significant increases in average profitability of $37 \%$, sales of $40 \%$, productive capital of $34 \%$, employment of $16 \%$, arrears to suppliers of $18 \%$, wage arrears of $34 \%$, and tax arrears of $29 \%$. 
Results of fixed-effects regressions (2) are presented in Table 3. They are very similar to the long-run results. Recipients of preferential treatments experience significantly higher employment and sales growth, investment, and growth in wage and tax arrears compared to firms that do not receive preferential treatments. A ten percent increase in the preferential treatment share in one year (from a mean value of 0.11 ; $\mathrm{SD}=0.16$ ) leads to increases in employment of $9.7 \%$, sales of $9.7 \%$, fixed capital of $6.7 \%$, wage arrears of $13.5 \%$, and tax arrears of $6.5 \%$. Hellman, Jones, and Kaufmann (2003) report that firms do not expect benefits from political power to be sustained in the long run. Our results show that performance gains from political influence are persistent.

Performance of firms with no political power in environments with high and low capture

Second, we investigate how regional capture affects firms with no political power. We run between-effects regressions for performance and investment on the subsample of firms that did not receive any preferential treatment:

$\overline{y_{f}}=\alpha_{1} \overline{P T \_ \text {concentr }_{f}}+\alpha_{2} \overline{P T_{-} \text {number }_{f}}+\alpha_{3} y_{f t_{0}}+\alpha_{4}$ controls $+\varepsilon_{f}$.

Again, we run both IV and OLS regressions. In IV regressions, preferential treatment concentration and the number of preferential treatments are instrumented by their initial values. ${ }^{17}$ The firm-level and industry-level controls are the same as in equation (2). Since our main variable of interest now is measured at the regional level, we use the following regional-level controls instead of region fixed effects: the proportion of the regional population with higher education, the size of the regional population, the share of oil and gas industries in regional industrial production, and initial regional per capita investment. Error terms are clustered within regions.

The results are again consistent with our hypothesis. Firms that have no political connections invest more and perform better in regions where political power is less concentrated. The results of IV and OLS regressions go in the same direction, but the OLS results are somewhat weaker. The cross-section results are illustrated in the second chart of Figure 1. This chart presents the means of 
performance indicators (with confidence intervals) for firms that did not receive preferential treatments in two groups of regions, where regions are sorted into groups according to the residual preferential treatment concentration after accounting for the number of preferential treatments. Among firms with no political power, investment, growth in sales, and productivity are significantly higher when firms are located in regions with low capture compared to when they are located in regions with high capture. IV regression results are presented in the first five columns of Table 4: A one standard deviation increase in the log preferential treatment concentration in a region leads to decreases in labor productivity growth of $29 \%$, sales growth of $36 \%$, and investment of $29 \%$ in an average large firm that does not have political power. ${ }^{18}$ The coefficients of preferential treatment concentration in regressions for other indicators of firm performance also have the predicted negative sign (but are insignificant). As a robustness check, we run the same regression on a larger sample of firms. To the subsample of firms that have no preferential treatments in our sample, we add firms from the $A L B A$ dataset that are not in our primary sample and operate in the same industries and regions as the firms in our primary sample. We do not have information on preferential treatments for these firms, but they are sufficiently small to assume that they have no political power. The results are similar (not reported): in all regressions, the coefficients of PT_concentr are negative. A one standard deviation increase in the log preferential treatment concentration leads to significant decreases in profitability, sales, and employment growth in an average firm of $43 \%, 30 \%$, and $25 \%$, respectively.

Performance of firms that are treated preferentially in environments with high and low capture

How does regional capture affect firms-recipients of preferential treatments? We run between-effects regressions for performance and investment on the subsample of firms that receive preferential treatments, limiting the analysis to years in which these firms were treated preferentially. We use the same specification (3) as above. Cross-sectional results are illustrated in 
the third chart of Figure 1: firms-recipients of preferential treatments on average have higher performance when preferential treatments are concentrated; but only two out of five differences are significant. The IV regression results are presented in the last five columns of Table 4. A one standard deviation increase in preferential treatment concentration leads to increases in labor productivity growth of $85 \%$, sales growth of $100 \%$, and investment growth of $56 \%$ in firms that receive preferential treatments.

Next, we study the effect of capture on regional economies.

\section{Effects of capture on aggregate growth and small business growth}

We use two alternative proxies for small business development: log share of small business employment and log retail turnover per capita. ${ }^{19}$ Aggregate economic growth is measured by the change in gross regional product per capita. To study the relationship in the long run, we run between-effects regressions. Specifications of these regressions are analogous to equation (3), with the only difference that the data are at the level of regions rather than firms. We control for initial level of the dependent variable, initial level of regional education (with the share of labor force that attained higher education), and size of the region (with log population); we also include year dummies. In regressions for small business, the outside option for employees of the small-business sector is controlled for with the average wage in the industrial sector. In the GRP growth regression, we control for the initial level of regional investment and the share of the oil and gas industry. ${ }^{20}$ As above, we run both OLS and IV regressions. In IV regressions, both the preferential treatment concentration and the number of preferential treatments are instrumented. Preferential treatment concentration is instrumented with two variables: the initial preferential treatment concentration and a dummy for ethnic republic. The first instrument reflects persistence of capture; the second measures the extent of political cohesion, which is generally smaller in ethnic republics. ${ }^{21}$ The 
number of preferential treatments is instrumented by the average number of preferential treatments in the three initial years.

Figure 2 illustrates cross-section regression results for all regional-level between effects regressions; it presents partial residual scatter plots of relationships between capture and dependent variables after accounting for control variables. The first two plots show significant residual correlation of capture, on the one hand, and small business growth and growth in retail turnover, on the other. The results of the corresponding IV regressions are presented in the first two columns of Table 5. Small business development is significantly negatively related to capture. A one standard deviation increase in the average preferential treatment concentration leads to a $6 \%$ decrease in retail turnover and a $10 \%$ decrease in the share of small business employment. ${ }^{22}$

In addition, we study the short-run relationship between capture and small business with fixed-effects OLS regressions: measures of regional small business are regressed on the lagged preferential treatment concentration controlling for the lagged number of preferential treatments, lagged population, and industry wage instrumented by its lagged value. ${ }^{23}$ The results are presented in the second two columns of Table 5. In the short run, preferential treatment concentration has a significant negative effect on the share of small business employment. A one standard deviation increase in the preferential treatment concentration leads to a decrease in the share of small business employment of $2.4 \%$ in the same year. ${ }^{24}$

Overall, our hypothesis that vested interests get in the way of small-business growth finds support in the data. In contrast, aggregate growth is unaffected by capture. There is no statistically significant relationship between preferential treatment concentration, on the one hand, and six-year growth of GRP per capita, on the other (see column 5 of Table 5).

$\underline{\text { Tax collection and arrears }}$ 
We study the effect of capture on tax capacity of the state using fixed-effects regressions analogous to the specification used for small-business growth in the short run. Gross regional product is included in the list of regressors to control for the size of regional tax base. Plots in the second row of Figure 2 illustrate the cross-section results. Concentration of preferential treatments (controlling for their number) is negatively correlated with tax revenues; is positively correlated with federal tax arrears; and is uncorrelated with regional tax arrears. The last three columns of Table 5 present the results of IV regressions: Holding regional product and the number of preferential treatments constant, a one standard deviation increase in the preferential treatment concentration leads to a $1.2 \%$ decrease in regional tax revenues and a $2.7 \%$ increase in federal tax arrears. $^{25}$ The coefficient of preferential treatment concentration in the regression for regional tax arrears is insignificant and smaller in magnitude than in regression for federal arrears. This result supports the view that Russia's regional governments protect firms from paying federal taxes. ${ }^{26}$

\section{$\underline{\text { An alternative story }}$}

Stigler (1971) discusses two alternative views on the nature of regulation: public choice versus public interest. According to the public choice theory, regulation is captured by and benefits special interests. In contrast, the public interest theory presumes that regulation is instituted for protection of the public and benefits the public. One can argue that special interests are not the only possible reason for concentration of preferential treatments. Welfare-maximizing and opportunistic career-motivated politicians may want to appeal to the majority by giving out preferential treatments to infant industries (for temporarily protection from competition), to foreign direct investors (to attract foreign capital to the region), to firms in distress (to internalize the social costs of bankruptcy), and to firms with high employment (for redistribution purposes) (Gray, 1973, 1975, Corden, 1974, and Baldwin, 1982). If, however, one recognizes that firms that may receive preferential treatments from the government behave strategically in order to obtain preferential 
treatment, one is back in the world of special interests politics, as firms use the political objectives of government officials in order to obtain rents. The literature on soft budget constraints (see Shleifer and Vishny, 1994; Boycko, Shleifer and Vishny, 1996; and Bennedsen, 2000) illustrates this point by focusing on bargaining between politicians and firms over excess employment. In our case, it is particularly unlikely that firms take legislation and regulations as given because we look at the largest firms in each region and because preferential treatments in our dataset are given to specific individual firms. Thus, our presumption is that firms actively seek preferential treatment.

A number of reality checks on our measures of firms’ political influence and regional-level capture suggest that concentration of preferential treatments, indeed, reflects subversion of government institutions. First, the residuals of preferential treatment concentration after controlling for the total number of preferential treatments are highly significantly correlated with other measures of state capture that are available for a limited number of years and regions. These measures come from expert evaluations and surveys. For example, preferential treatment concentration has a correlation coefficient of 0.4 (significant at a $1 \%$ significance level) with the Transparency International (TI) and Information for Democracy (INDEM) state capture rating. ${ }^{27}$ Figure 3 illustrates this correlation. Preferential treatment concentration is also negatively correlated with the Institute of Free Media regional index of press freedom (correlation coefficient is -0.4, significant at a $1 \%$ significance level) ${ }^{28}$ In addition, preferential treatment concentration for a given number of preferential treatments is positively significantly correlated with various measures of administrative corruption (also available from TI and INDEM). Regional poverty and unemployment are unrelated to past, present, or future preferential treatment concentration. At the firm level, the best predictors of the share of preferential treatments are proxies for the firm size. Controlling for size, however, the share of favorable legislation is positively significantly correlated 
with increases in firm's profitability. These pieces of evidence suggest that our measures adequately reflect variation in regulatory capture.

\section{Conclusions}

This paper investigates the effects of capture of legislature and regulatory agencies by few politically powerful firms on growth of these firms, growth of firms that do not exercise political influence, and on aggregate growth. We construct measures of regional capture and firm's political power based on unique micro-level data on preferential treatment of individual firms by regional laws and regulations.

The key findings can be summarized as follows.

1) Political power yields substantial performance gains to firms. Politically powerful firms enjoy higher growth in profitability, sales, and employment compared to their counterparts. Firms with political power are also found to have better outcomes of bargaining with workers, suppliers, and tax collectors: despite the performance gains, they are able to sustain higher growth in wage, trade, and tax arrears. 2) Capture hurts firms that do not have political power: their investment and performance decrease with an increase in the level of capture. 3) Firms benefit more from preferential treatments by regional authorities in regions with higher levels of capture. 4) Capture negatively affects small business growth and government revenue. 5) There is no evidence that capture had a significant impact on aggregate regional growth over a six-year period.

Capture of legislation by few large firms is only the tip of the iceberg of the broader phenomenon of subversion of law and order. Following Olson (1965) and Stigler (1971), we document that large firms obtain regulations and laws that benefit them at the expense of other economic agents. Some examples of the adverse effects of captured regulations and laws are as follows: firms with no political power suffer from unfair competition and trade arrears; employees 
of politically powerful firms are not paid wages in full; and the general public is affected through poorer public-goods provision because the tax capacity of the state decreases with capture.

Olson (1982) argued that capture necessarily hurts aggregate growth. Even though we found that aggregate growth was not significantly affected by capture, in the context of a transition economy the result that capture creates obstacles to small-business development may have severe long-term growth implications because it becomes an impediment to asset reallocation from an old, rigid, and unproductive sector to a new, dynamic, and more productive sector. 
Table 1. Summary statistics of measures of regional capture and firms' political influence

\begin{tabular}{|c|c|c|c|c|c|c|}
\hline & Obs & Mean & SD & Min & Median & Max \\
\hline \multicolumn{7}{|l|}{ Firms: } \\
\hline Share of preferential treatments & 7,167 & 0.15 & 0.16 & 0 & 0.2 & 1 \\
\hline Average across-years share of preferential treatments & 962 & 0.15 & 0.09 & 0 & 0.13 & 0.79 \\
\hline $\begin{array}{l}\text { Average share of preferential treatments for two consecutive years } \\
\text { Log of average across years preferential treatment concentration for the }\end{array}$ & 3,526 & 0.11 & 0.16 & 0 & 0.1 & 1 \\
\hline $\begin{array}{l}\text { subsample of firms that do not receive preferential treatments } \\
\text { Average across vears preferential treatment concentration for the subsample }\end{array}$ & 518 & -0.99 & 0.29 & -1.6 & -0.78 & -0.20 \\
\hline of firms that receive preferential treatments & 149 & 0.38 & 0.22 & 0.20 & 0.32 & 1 \\
\hline Total number of preferential treatments & 7,284 & 0.14 & 0.41 & 0 & 0 & 4 \\
\hline \multicolumn{7}{|l|}{ Regions: } \\
\hline Preferential treatment concentration ${ }^{\nabla}$ & 667 & 0.40 & 0.29 & 0.20 & 0.20 & 1 \\
\hline Total number of preferential treatments in the region & 667 & 1.41 & 1.99 & 0 & 0 & 11 \\
\hline Across years average of preferential treatment concentration & 73 & 0.42 & 0.12 & 0.23 & 0.84 & 0.4 \\
\hline
\end{tabular}

$\nabla^{7}$ The mean value of preferential treatment concentration (0.40) corresponds to the common situation when in a particular year one firm in a region receives two preferential treatments, another two receive one preferential treatment each, and all other firms do not receive preferential treatments. 
Table 2. Firm performance and preferential treatments (between-effects regressions)

\begin{tabular}{|c|c|c|c|c|c|c|c|c|}
\hline & $\begin{array}{l}\text { Labor } \\
\text { produc- } \\
\text { tivity }\end{array}$ & $\begin{array}{l}\text { Profitabi- } \\
\quad \text { lity }\end{array}$ & Sales & $\begin{array}{l}\text { Fixed } \\
\text { capital }\end{array}$ & $\begin{array}{l}\text { Employ- } \\
\text { ment }\end{array}$ & $\begin{array}{l}\text { Wage } \\
\text { arrears }\end{array}$ & $\begin{array}{l}\text { Arrears to } \\
\text { suppliers }\end{array}$ & $\begin{array}{l}\text { Arrears to } \\
\text { budget }\end{array}$ \\
\hline \multirow{3}{*}{$\begin{array}{l}\text { Firm’s share of preferential } \\
\text { treatments (Instr-d) }\end{array}$} & -6.19 & 24.56 & 26.58 & 22.85 & 10.71 & 22.58 & 11.41 & 18.46 \\
\hline & (3.73) & $(10.63)^{* *}$ & $(12.13) * *$ & $(12.50) *$ & $(4.19) * *$ & $(7.06)^{* * *}$ & $(4.88)^{* *}$ & $(4.90) * * *$ \\
\hline & 0.35 & 0.27 & 0.22 & 0.58 & 0.67 & 0.36 & 0.5 & 0.4 \\
\hline Initial level of depend variable & $(0.04)^{* * *}$ & $(0.06)^{* * *}$ & $(0.09) * *$ & $(0.09)^{* * *}$ & $(0.05)^{* * *}$ & $(0.12)^{* * *}$ & $(0.11)^{* * *}$ & $(0.06)^{* * *}$ \\
\hline \multirow{2}{*}{ Initial national market share } & -0.24 & -0.66 & & 0.68 & & 4.24 & 1.11 & 4.31 \\
\hline & $(0.67)$ & $(2.88)$ & & $(1.22)$ & & $(3.00)$ & $(2.15)$ & $(2.50)^{*}$ \\
\hline \multirow{2}{*}{ New enterprise dummy } & 0.14 & 1.71 & 1.38 & -0.15 & 0.62 & 0.51 & 0.72 & 0.37 \\
\hline & $(0.29)$ & $(0.66) * *$ & $(0.54)^{* *}$ & $(0.31)$ & $(0.25) * *$ & $(0.48)$ & $(0.27) * *$ & $(0.40)$ \\
\hline \multirow{2}{*}{ Dropped out dummy } & 0.56 & 0.07 & -0.51 & 1.00 & -0.37 & & & \\
\hline & $(0.24)^{* *}$ & $(0.52)$ & $(0.61)$ & $(0.67)$ & $(0.20)^{*}$ & & & \\
\hline \multirow{2}{*}{ State enterprise dummy } & -0.17 & -0.43 & -0.43 & -0.61 & -0.12 & -1.2 & -0.61 & -0.9 \\
\hline & $(0.11)$ & $(0.37)$ & $(0.22)^{*}$ & $(0.46)$ & $(0.16)$ & $(0.67)^{*}$ & $(0.35)^{*}$ & $(0.60)$ \\
\hline \multirow[t]{2}{*}{ Constant } & 3.82 & 3.07 & 5.53 & 1.75 & 0.62 & 1.81 & 3.96 & 2.2 \\
\hline & $(0.51)^{* * *}$ & $(1.30) * *$ & $(1.03) * * *$ & (1.13) & $(0.48)$ & $(0.81)^{* *}$ & $(0.94)^{* * *}$ & $(0.74)^{* * *}$ \\
\hline Industry dummies & Yes & Yes & Yes & Yes & Yes & Yes & Yes & Yes \\
\hline Regional fixed effects & Yes & Yes & Yes & Yes & Yes & Yes & Yes & Yes \\
\hline Observations & 5274 & 5061 & 5512 & 5293 & 5462 & 1479 & 1472 & 1474 \\
\hline Number of firms & 861 & 874 & 873 & 886 & 898 & 667 & 667 & 667 \\
\hline \multicolumn{9}{|l|}{ F-statistics for the instrument } \\
\hline in the first stage & 15.17 & 12.93 & 7.69 & 6.79 & 6.69 & 12.61 & 10.73 & 13.38 \\
\hline
\end{tabular}

Note: All dependent variables are in logs. In all regressions but the regression with fixed capital as dependent variable, the share of preferential treatments is instrumented by the initial relative size of fixed capital. In the regression with fixed capital as dependent variable, the share of preferential treatments is instrumented by the initial relative employment size. The choice of instruments is driven by their explanatory power in the first-stage regression. Robust standard errors clustered at the regional level are in parentheses. * significant at 10\%; ** significant at $5 \% ; * * *$ significant at $1 \%$.. 
Table 3. Firm performance and preferential treatments (fixed-effects regressions)

\begin{tabular}{|c|c|c|c|c|c|c|c|c|}
\hline & $\begin{array}{c}\text { Labor } \\
\text { produc- } \\
\text { tivity }\end{array}$ & $\begin{array}{l}\text { Profita- } \\
\text { bility }\end{array}$ & Sales & $\begin{array}{l}\text { Fixed } \\
\text { capital }\end{array}$ & $\begin{array}{l}\text { Employ- } \\
\text { ment }\end{array}$ & $\begin{array}{l}\text { Wage } \\
\text { arrears }\end{array}$ & $\begin{array}{l}\text { Arrears to } \\
\text { suppliers }\end{array}$ & $\begin{array}{l}\text { Arrears to } \\
\text { budget }\end{array}$ \\
\hline $\begin{array}{l}\text { Firm’s share of preferential } \\
\text { treatments (Instr-d) }\end{array}$ & $\begin{array}{l}-1.73 \\
(1.60)\end{array}$ & $\begin{array}{c}4.34 \\
(3.35)\end{array}$ & $\begin{array}{c}8.86 \\
(3.47)^{* *}\end{array}$ & $\begin{array}{c}6.10 \\
(2.03)^{* * *}\end{array}$ & $\begin{array}{c}8.83 \\
(2.99)^{* * *}\end{array}$ & $\begin{array}{c}12.30 \\
(5.30)^{* *}\end{array}$ & $\begin{array}{l}2.55 \\
(2.11)\end{array}$ & $\begin{array}{c}6.01 \\
(3.06)^{* *}\end{array}$ \\
\hline $\begin{array}{l}\text { Lag of residual preferential treatment } \\
\text { concentration }\end{array}$ & $\begin{array}{l}-0.06 \\
(0.10)\end{array}$ & $\begin{array}{c}0.24 \\
(0.20)\end{array}$ & $\begin{array}{c}0.56 \\
(0.21)^{* * *}\end{array}$ & $\begin{array}{c}0.35 \\
(0.12)^{* * *}\end{array}$ & $\begin{array}{c}0.49 \\
(0.18)^{* * *}\end{array}$ & $\begin{array}{c}0.62 \\
(0.29)^{* *}\end{array}$ & $\begin{array}{c}0.20 \\
(0.11)^{*}\end{array}$ & $\begin{array}{c}0.41 \\
(0.18)^{* *}\end{array}$ \\
\hline $\begin{array}{l}\text { Lag of the number of preferential } \\
\text { treatments }\end{array}$ & $\begin{array}{l}-0.02 \\
(0.01)\end{array}$ & $\begin{array}{c}0.05 \\
(0.03)^{*}\end{array}$ & $\begin{array}{c}0.06 \\
(0.03)^{* *}\end{array}$ & $\begin{array}{c}0.05 \\
(0.02)^{* *}\end{array}$ & $\begin{array}{c}0.07 \\
(0.03)^{* *}\end{array}$ & $\begin{array}{c}0.07 \\
(0.04)^{*}\end{array}$ & $\begin{array}{c}0.03 \\
(0.02)^{*}\end{array}$ & $\begin{array}{c}0.02 \\
(0.03)\end{array}$ \\
\hline Lag of national market share & $\begin{array}{c}2.17 \\
(0.57)^{* * *}\end{array}$ & $\begin{array}{l}-0.29 \\
(1.60)\end{array}$ & & $\begin{array}{l}-1.30 \\
(1.00)\end{array}$ & & $\begin{array}{c}4.50 \\
(2.54)^{*}\end{array}$ & $\begin{array}{l}1.36 \\
(0.99)\end{array}$ & $\begin{array}{c}1.77 \\
(1.69)\end{array}$ \\
\hline Regional trend & $\begin{array}{c}-0.05 \\
(0.02)^{*}\end{array}$ & $\begin{array}{c}0.08 \\
(0.03)^{* * *}\end{array}$ & $\begin{array}{c}0.02 \\
(0.06)\end{array}$ & $\begin{array}{c}0.05 \\
(0.09)\end{array}$ & $\begin{array}{c}0.11 \\
(0.19)\end{array}$ & $\begin{array}{l}-0.01 \\
(0.11)\end{array}$ & $\begin{array}{c}0.02 \\
(0.05)\end{array}$ & $\begin{array}{c}0.09 \\
(0.10)\end{array}$ \\
\hline Industry trend & $\begin{array}{c}0.81 \\
(0.10)^{* * *}\end{array}$ & $\begin{array}{c}0.11 \\
(0.04)^{* * *}\end{array}$ & $\begin{array}{l}-0.01 \\
(0.09)\end{array}$ & $\begin{array}{c}0.53 \\
(0.28)^{*}\end{array}$ & $\begin{array}{c}0.40 \\
(0.22)^{*}\end{array}$ & $\begin{array}{l}-0.02 \\
(0.25)\end{array}$ & $\begin{array}{c}0.13 \\
(0.10)\end{array}$ & $\begin{array}{c}0.36 \\
(0.21)^{*}\end{array}$ \\
\hline Year dummies & Yes & Yes & Yes & Yes & Yes & Yes & Yes & Yes \\
\hline $\begin{array}{l}\text { Fixed effects for firms } \\
\text { Observations }\end{array}$ & $\begin{array}{c}\text { Yes } \\
2623\end{array}$ & $\begin{array}{l}\text { Yes } \\
2545\end{array}$ & $\begin{array}{l}\text { Yes } \\
2791\end{array}$ & $\begin{array}{l}\text { Yes } \\
2590\end{array}$ & $\begin{array}{l}\text { Yes } \\
2697\end{array}$ & $\begin{array}{l}\text { Yes } \\
1408\end{array}$ & $\begin{array}{l}\text { Yes } \\
1392\end{array}$ & $\begin{array}{l}\text { Yes } \\
1390\end{array}$ \\
\hline Number of firms & 761 & 735 & 783 & 753 & 765 & 619 & 616 & 618 \\
\hline $\begin{array}{l}\text { F-statistics for the instrument in the } \\
\text { first stage }\end{array}$ & 6.75 & 13.54 & 8.97 & 13.25 & 9.35 & 6.80 & 6.88 & 10.50 \\
\hline
\end{tabular}

Note: All dependent variables are in logs. In all regressions, the share of preferential treatments is instrumented by the two-year lag of employment share. In order for the instrument to be correlated with the average firm's share of preferential treatments, observations were excluded from the sample when annual number of regional preferential treatments is zero. Robust standard errors clustered at the regional level are in parentheses. * significant at 10\%; ** significant at 5\%; *** significant at $1 \%$. 
Table 4. Effect of capture on firms that do and do not receive preferential treatments

\begin{tabular}{|c|c|c|c|c|c|c|c|c|c|c|}
\hline & \multicolumn{5}{|c|}{ Subsample of firms without preferential treatments } & \multicolumn{5}{|c|}{ Subsample of firms with preferential treatments } \\
\hline & $\begin{array}{c}\text { Labor } \\
\text { produc- } \\
\text { tivity }\end{array}$ & $\begin{array}{c}\text { Profita- } \\
\text { bility }\end{array}$ & Sales & $\begin{array}{c}\text { Fixed } \\
\text { capital }\end{array}$ & $\begin{array}{c}\text { Employ- } \\
\text { ment }\end{array}$ & $\begin{array}{c}\text { Labor } \\
\text { produc- } \\
\text { tivity }\end{array}$ & $\begin{array}{c}\text { Profita- } \\
\text { bility }\end{array}$ & Sales & $\begin{array}{c}\text { Fixed } \\
\text { capital }\end{array}$ & $\begin{array}{c}\text { Employ- } \\
\text { ment }\end{array}$ \\
\hline \multirow[t]{2}{*}{ Preferential treatment concentration (Instr-d) } & -1.00 & -0.63 & -1.25 & -0.99 & -0.17 & 3.85 & 0.93 & 4.54 & 2.53 & -0.04 \\
\hline & $(0.35)^{* * *}$ & $(0.44)$ & $(0.54)^{* *}$ & $(0.34)^{* * *}$ & $(0.17)$ & $(1.10)^{* * *}$ & (3.34) & $(0.90) * * *$ & $(1.41)^{*}$ & $(0.69)$ \\
\hline \multirow[t]{2}{*}{ Number of preferential treatments (Instr-d) } & 0.12 & 0.03 & 0.29 & 0.09 & 0.04 & 0.21 & -0.36 & 0.22 & 0.32 & -0.02 \\
\hline & $(0.10)$ & $(0.18)$ & $(0.14)^{* *}$ & $(0.08)$ & $(0.06)$ & $(0.11)^{*}$ & $(0.23)$ & $(0.10)^{* *}$ & $(0.09)^{* * *}$ & $(0.07)$ \\
\hline \multirow[t]{2}{*}{ Initial level of depend variable } & 0.23 & 0.23 & 0.44 & 0.60 & 0.82 & 0.60 & 0.19 & 0.82 & 0.71 & 0.81 \\
\hline & $(0.04)^{* * *}$ & $(0.05)^{* * *}$ & $(0.05)^{* * *}$ & $(0.04)^{* * *}$ & $(0.03) * * *$ & $(0.11)^{* * *}$ & $(0.09)^{* *}$ & $(0.06) * * *$ & $(0.14)^{* * *}$ & $(0.06) * * *$ \\
\hline \multirow[t]{2}{*}{ Share of oil \& gas in regional industrial production } & -0.43 & -0.21 & -0.32 & 0.04 & -0.16 & 0.82 & -2.48 & 0.70 & 0.71 & -0.51 \\
\hline & $(0.27)$ & $(0.51)$ & $(0.36)$ & $(0.20)$ & $(0.18)$ & $(0.54)$ & $(1.11)^{* *}$ & $(0.46)$ & $(0.29) * *$ & $(0.44)$ \\
\hline \multirow[t]{2}{*}{ New enterprise dummy } & 0.59 & 0.87 & 0.41 & -0.02 & 0.11 & 0.38 & 0.72 & -0.03 & 0.13 & 0.00 \\
\hline & $(0.09)^{* * *}$ & $(0.19)^{* * *}$ & $(0.10)^{* * *}$ & $(0.09)$ & $(0.07)$ & $(0.19)^{*}$ & $(0.44)$ & $(0.21)$ & $(0.19)$ & $(0.15)$ \\
\hline \multirow[t]{2}{*}{ State enterprise dummy } & -0.47 & -0.49 & -0.38 & -0.11 & -0.02 & -0.08 & -0.26 & -0.05 & -0.08 & -0.15 \\
\hline & $(0.14)^{* * *}$ & $(0.21)^{* *}$ & $(0.18)^{* *}$ & $(0.08)$ & $(0.07)$ & (0.19) & $(0.44)$ & $(0.15)$ & $(0.21)$ & $(0.12)$ \\
\hline \multirow[t]{2}{*}{ Size of regional population } & 0.29 & 0.20 & 0.57 & 0.05 & 0.16 & 0.14 & 0.09 & 0.22 & 0.10 & 0.11 \\
\hline & $(0.06)^{* * *}$ & $(0.11)^{*}$ & $(0.13)^{* * *}$ & $(0.04)$ & $(0.05) * * *$ & $(0.10)$ & $(0.21)$ & $(0.11)^{* *}$ & $(0.05)^{*}$ & $(0.04)^{* *}$ \\
\hline \multirow[t]{2}{*}{ Initial share of educated population } & -0.02 & -0.03 & -0.08 & -0.02 & -0.01 & 0.04 & 0.08 & -0.01 & 0.01 & -0.03 \\
\hline & $(0.01)$ & $(0.02)$ & $(0.02)^{* * *}$ & $(0.01)$ & $(0.01)^{*}$ & $(0.03)$ & $(0.04)^{* *}$ & $(0.02)$ & $(0.02)$ & $(0.02)^{*}$ \\
\hline \multirow[t]{2}{*}{ Initial regional investment } & 0.39 & 0.58 & 0.63 & 0.24 & -0.02 & -0.29 & 0.88 & -0.17 & -0.23 & 0.16 \\
\hline & $(0.11)^{* * *}$ & $(0.15)^{* * *}$ & $(0.17)^{* * *}$ & $(0.08)^{* * *}$ & $(0.08)$ & $(0.21)$ & $(0.41)^{* *}$ & $(0.19)$ & $(0.12)^{*}$ & $(0.20)$ \\
\hline \multirow[t]{2}{*}{ Initial national market share } & 2.74 & 2.55 & 8.32 & 0.51 & 1.72 & 4.67 & 0.72 & 0.90 & 1.62 & 0.39 \\
\hline & $(0.99) * * *$ & $(1.47)^{*}$ & $(2.13)^{* * *}$ & (0.93) & $(0.66)^{* *}$ & $(0.60)^{* * *}$ & $(1.41)$ & $(2.50)$ & $(0.52)^{* * *}$ & $(0.45)$ \\
\hline Industry dummies & Yes & Yes & Yes & Yes & Yes & Yes & Yes & Yes & Yes & Yes \\
\hline \multirow[t]{2}{*}{ Constant } & -1.83 & -4.18 & -2.36 & -0.73 & 0.44 & -0.05 & -5.34 & -0.79 & -0.13 & 0.18 \\
\hline & $(0.91)^{* *}$ & $(1.25)^{* * *}$ & $(1.36)^{*}$ & $(0.88)$ & $(0.56)$ & (1.04) & $(2.79)^{*}$ & (1.01) & $(0.87)$ & $(0.75)$ \\
\hline Observations & 1935 & 1856 & 2107 & 1898 & 1984 & 208 & 201 & 236 & 208 & 217 \\
\hline Number of firms & 441 & 425 & 449 & 432 & 440 & 115 & 112 & 128 & 115 & 117 \\
\hline F-st.for PT_concentr's ins-t & 31.00 & 38.20 & 24.43 & 25.41 & 31.15 & 6.07 & 2.08 & 3.05 & 4.12 & 3.96 \\
\hline F-st. for PT_number's instr-t & 24.67 & 23.51 & 27.58 & 21.12 & 27.27 & 4.64 & 2.39 & 3.94 & 3.67 & 4.86 \\
\hline
\end{tabular}

Note: All dependent variables are in logs. In the regressions for the subsample of firms with no political influence, we take log of PT_concentr to improve the quality of its instrument. PT_concentr, $\log \left(P T \_c o n c e n t r\right)$, and PT_number are instrumented by their initial values. Robust standard errors clustered at the regional level are in parentheses. * significant at $10 \%$; ** significant at $5 \%$; *** significant at $1 \%$.. 
Table 5. Regional-level regressions: effect of capture on small business growth, aggregate growth, and tax capacity

\begin{tabular}{|c|c|c|c|c|c|c|c|c|c|}
\hline \multirow[b]{2}{*}{ Speficication } & \multicolumn{4}{|c|}{ Small business growth } & \multirow{2}{*}{$\begin{array}{c}\text { Growth } \\
\mathrm{BE} \\
\end{array}$} & \multirow{2}{*}{$\frac{\text { Revenues }}{\text { FE }}$} & \multicolumn{3}{|c|}{ Tax arrears } \\
\hline & $\mathrm{BE}$ & $\mathrm{BE}$ & $\mathrm{FE}$ & $\mathrm{FE}$ & & & $\mathrm{FE}$ & $\mathrm{FE}$ & $\mathrm{FE}$ \\
\hline & $\begin{array}{c}\text { Small } \\
\text { business } \\
\text { employme } \\
\text { nt share }\end{array}$ & $\begin{array}{c}\text { Retail } \\
\text { turnover } \\
\text { per capita }\end{array}$ & $\begin{array}{c}\text { Small } \\
\text { business } \\
\text { employme } \\
\text { nt share }\end{array}$ & $\begin{array}{c}\text { Retail } \\
\text { turnover } \\
\text { per capita }\end{array}$ & $\begin{array}{c}\text { Change in } \\
\text { GRP per } \\
\text { capita }\end{array}$ & $\begin{array}{c}\text { Tax } \\
\text { revenues } \\
\text { per capita }\end{array}$ & $\begin{array}{c}\text { Regional } \\
\text { tax arrears } \\
\text { per capita }\end{array}$ & $\begin{array}{c}\text { Federal } \\
\text { tax arrears } \\
\text { per capita }\end{array}$ & $\begin{array}{c}\text { Total tax } \\
\text { arrears per } \\
\text { capita }\end{array}$ \\
\hline Preferential treatment concentration & $\begin{array}{c}-0.87 \\
(0.52)^{*}\end{array}$ & $\begin{array}{c}-0.49 \\
(0.27)^{*}\end{array}$ & $\begin{array}{c}-0.08 \\
(0.04)^{*}\end{array}$ & $\begin{array}{l}-0.01 \\
(0.02)\end{array}$ & $\begin{array}{c}0.46 \\
(0.33)\end{array}$ & $\begin{array}{c}-0.04 \\
(0.02)^{*}\end{array}$ & $\begin{array}{c}0.06 \\
(0.04)\end{array}$ & $\begin{array}{c}0.09 \\
(0.05)^{*}\end{array}$ & $\begin{array}{c}0.09 \\
(0.04)^{* *}\end{array}$ \\
\hline Number of preferential treatments & $\begin{array}{c}-0.02 \\
(0.04)\end{array}$ & $\begin{array}{c}0.03 \\
(0.03)\end{array}$ & $\begin{array}{c}-0.03 \\
(0.01)^{* * *}\end{array}$ & $\begin{array}{c}0.002 \\
(0.004)\end{array}$ & $\begin{array}{l}-0.02 \\
(0.04)\end{array}$ & $\begin{array}{c}0.004 \\
(0.004)\end{array}$ & $\begin{array}{l}0.004 \\
(0.01)\end{array}$ & $\begin{array}{c}0.01 \\
(0.01)\end{array}$ & $\begin{array}{c}0.01 \\
(0.01)\end{array}$ \\
\hline Log population & $\begin{array}{c}0.17 \\
(0.28)\end{array}$ & $\begin{array}{c}0.13 \\
(0.12)\end{array}$ & $\begin{array}{c}3.14 \\
(1.57)^{* *}\end{array}$ & $\begin{array}{c}1.33 \\
(0.34)^{* * *}\end{array}$ & $\begin{array}{c}0.01 \\
(0.04)\end{array}$ & $\begin{array}{c}1.6 \\
(0.72)^{* *}\end{array}$ & $\begin{array}{c}1.64 \\
(0.87)^{*}\end{array}$ & $\begin{array}{c}4.34 \\
(1.03)^{* * *}\end{array}$ & $\begin{array}{c}3.48 \\
(0.83)^{* * *}\end{array}$ \\
\hline Log wage & $\begin{array}{c}-0.1 \\
(0.09)\end{array}$ & $\begin{array}{c}0.62 \\
(0.07)^{* * *}\end{array}$ & $\begin{array}{c}1.35 \\
(0.70)^{*}\end{array}$ & $\begin{array}{c}0.78 \\
(0.10)^{* * *}\end{array}$ & & & & & \\
\hline Initial share of population with higher education & $\begin{array}{c}0.02 \\
(0.05)\end{array}$ & $\begin{array}{c}0.08 \\
(0.03)^{* * *}\end{array}$ & & & $\begin{array}{c}0.03 \\
(0.01)^{* * *}\end{array}$ & & & & \\
\hline Initial level of dependent variable & $\begin{array}{c}0.6 \\
(0.09)^{* * *}\end{array}$ & $\begin{array}{c}0.05 \\
(0.07)\end{array}$ & & & & & & & \\
\hline Share of oil \& gas industry & & & & & $\begin{array}{c}0.21 \\
(0.16)\end{array}$ & & & & \\
\hline Log of initial investment per capita & & & & & $\begin{array}{c}0.07 \\
(0.05)\end{array}$ & & & & \\
\hline Log GRP per capita & & & & & & $\begin{array}{c}1.35 \\
(0.22)^{* * *}\end{array}$ & $\begin{array}{c}0.55 \\
(0.26)^{* *}\end{array}$ & $\begin{array}{c}0.89 \\
(0.28)^{* * *}\end{array}$ & $\begin{array}{c}0.57 \\
(0.25)^{* *}\end{array}$ \\
\hline Constant & $\begin{array}{c}1.87 \\
(0.91)^{* *}\end{array}$ & $\begin{array}{c}3.04 \\
(0.55)^{* * *}\end{array}$ & $\begin{array}{c}-27.96 \\
(12.98)^{* *}\end{array}$ & $\begin{array}{c}-6.55 \\
(2.63)^{* *}\end{array}$ & $\begin{array}{c}-1.07 \\
(0.23)^{* * *}\end{array}$ & $\begin{array}{c}-7.78 \\
(5.49)\end{array}$ & $\begin{array}{c}-8.3 \\
(6.62)\end{array}$ & $\begin{array}{c}-28.85 \\
(7.81)^{* * *}\end{array}$ & $\begin{array}{c}-21.09 \\
(6.33)^{* * *}\end{array}$ \\
\hline Year and region fixed effects & & & Yes & Yes & & Yes & Yes & Yes & Yes \\
\hline Observations & 212 & 386 & 278 & 558 & 346 & 355 & 421 & 421 & 426 \\
\hline Number of regions & 72 & 65 & 71 & 72 & 70 & 71 & 72 & 71 & 72 \\
\hline R-squared & & & 0.01 & 0.21 & & 0.35 & 0.10 & 0.04 & 0.05 \\
\hline F-st for the instruments of PT_concentr & 4.6 & 6.04 & & & 9.16 & & & & \\
\hline F-st. for the instruments of $P T$ number & 14.76 & 6.98 & & & 14.62 & & & & \\
\hline
\end{tabular}

Note: Robust standard errors are in parentheses; * significant at 10\%; ** significant at 5\%; *** significant at $1 \%$. In the between-effects regressions, PT_concentr is instrumented by the initial PT_concentr and a dummy for ethnic republic; PT_number is instrumented by the initial value. PT_concentr and PT_number are lagged in

fixed-effects regressions. Log wage and log GRP per capita is instrumented by lagged values in fixed-effects regressions and by initial values in between-effects

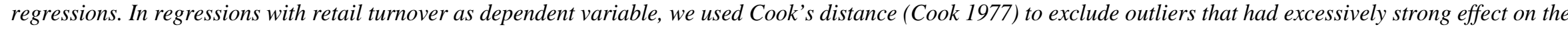
estimates. In the growth regression, we subtract the initial value from GRP per capita instead of including it as a control in order to improve quality of instruments. 
Figure 1. Basic regularities in the firm-level data

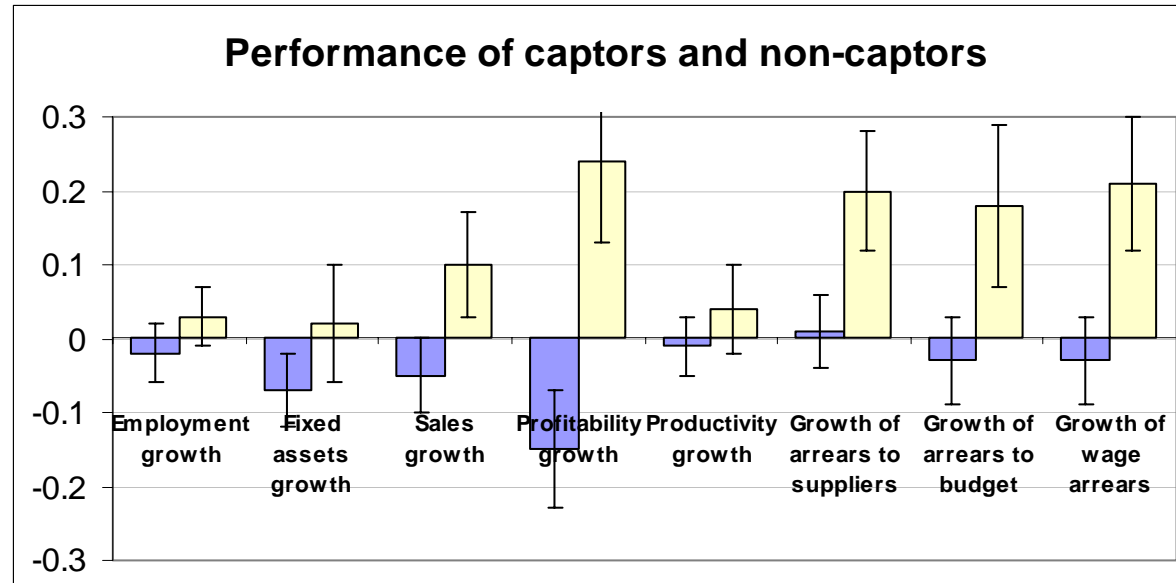

Non-captor firms $\square$ Firms-captors
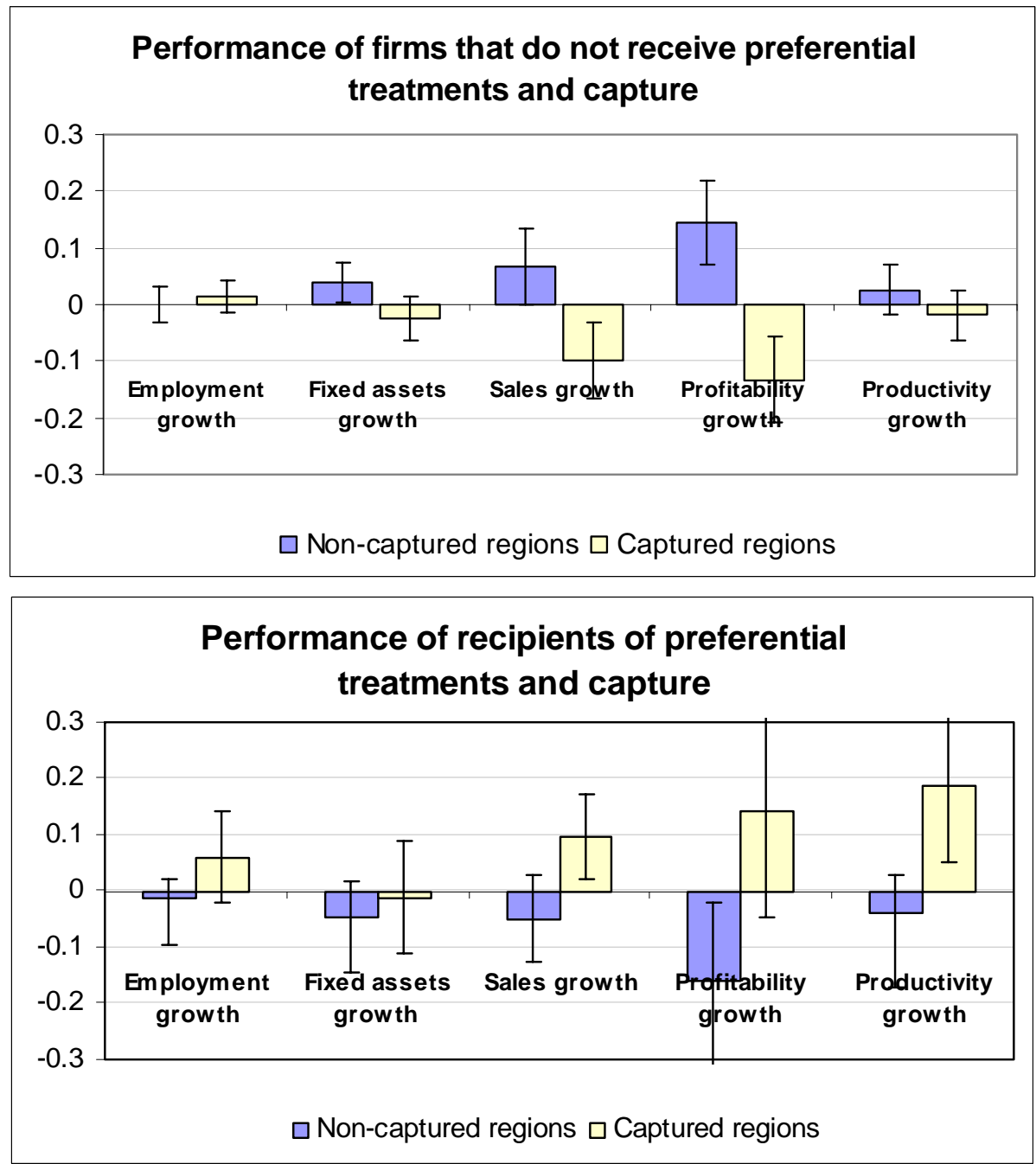

Note: In the first chart, "captor" and "non-captor" firms are defined as firms in the top and bottom thirds of the distribution with respect to the average share of preferential treatments, respectively. In the second and third charts, "captured" and "noncaptured" regions are defined as regions in the top and bottom thirds of the distribution with respect to the value of the average residual preferential treatment concentration, respectively. Black bars indicate 95\% confidence intervals. 
Figure 2. Cross-sectional residual correlation of indicators of regional performance and capture after accounting for control variables
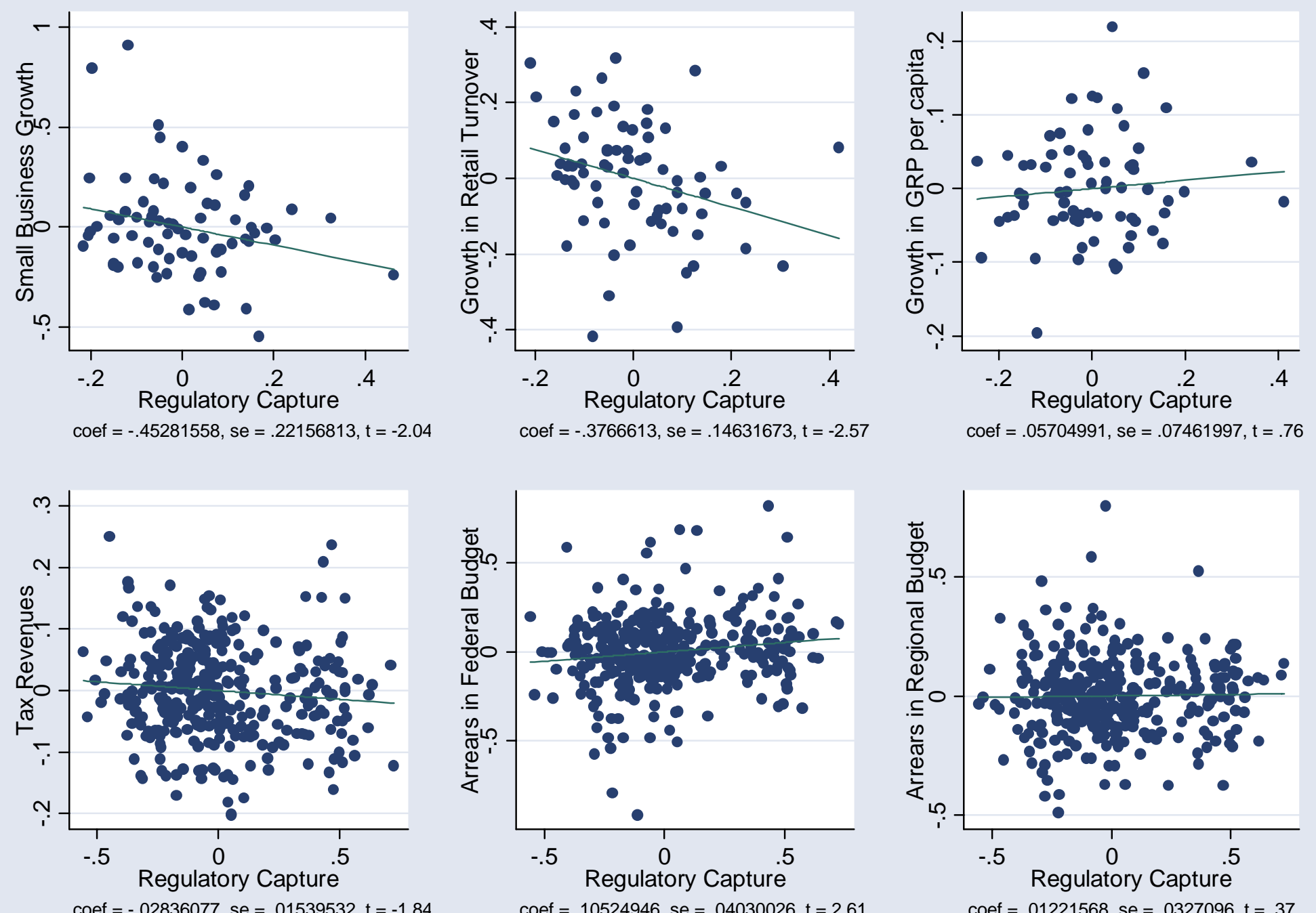
Figure 3. Cross-sectional residual correlation of TI \& INDEM capture index and concentration of preferential treatments (our measure of capture) after accounting for the regional number of preferential treatments

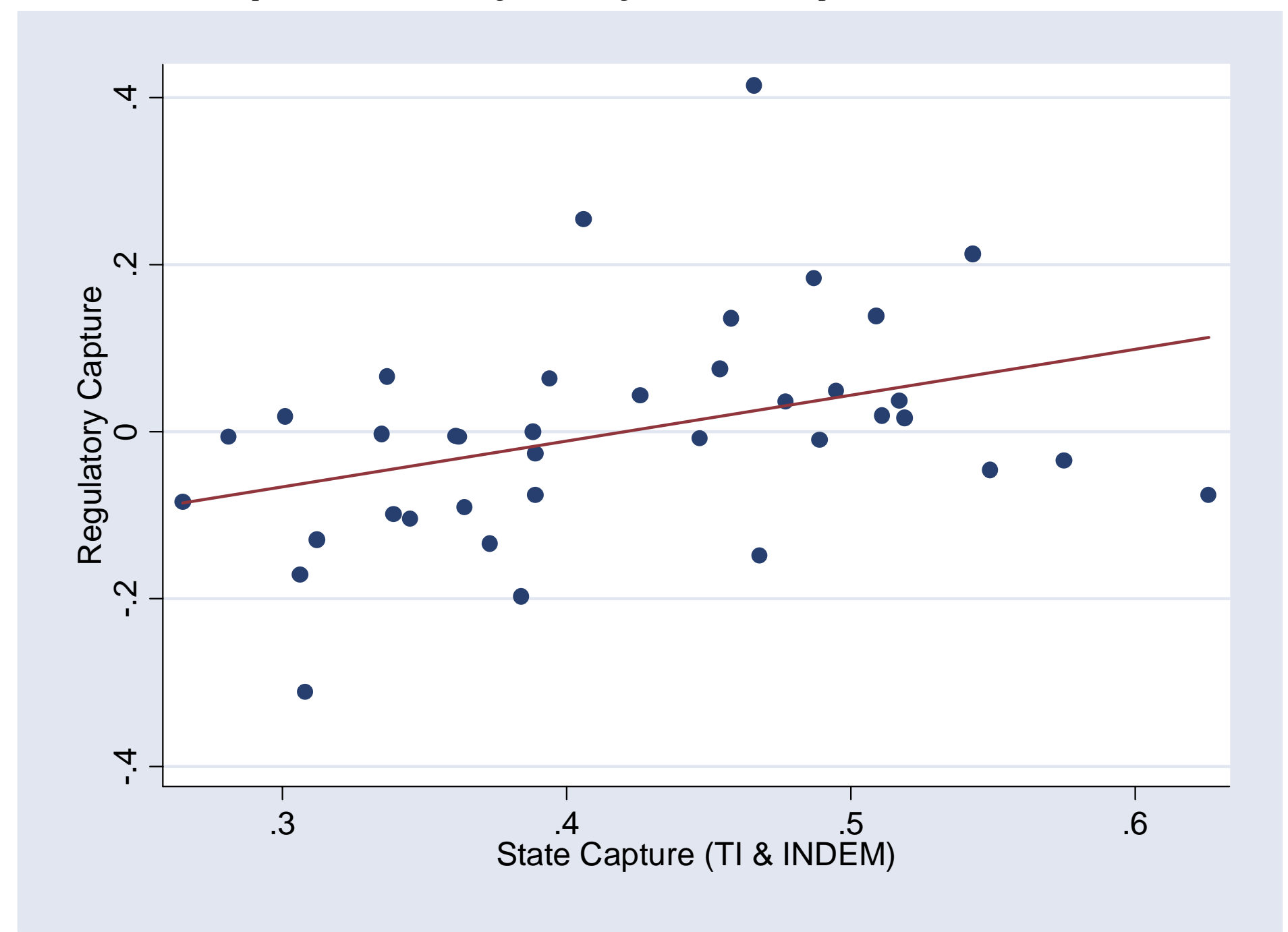




\section{APPENDIX}

Table A1. Construction of the preferential treatment concentration measure

\begin{tabular}{|c|c|c|c|c|c|c|c|c|c|}
\hline \multirow[b]{2}{*}{ Years: } & \multicolumn{9}{|c|}{ Preferential treatments } \\
\hline & 1992 & 1993 & 1994 & 1995 & 1996 & 1997 & 1998 & 1999 & 2000 \\
\hline \multicolumn{10}{|l|}{ Firms in Arkhangelsk oblast } \\
\hline "Severodvinskaya Heating Station” & 0 & 0 & 0 & 1 & 0 & 0 & 0 & 0 & 0 \\
\hline The other 16 firms from the region & 0 & 0 & 0 & 0 & 0 & 0 & 0 & 0 & 0 \\
\hline Regional preferential treatment concentration & 0.2 & 0.2 & 0.2 & 1 & 0.2 & 0.2 & 0.2 & 0.2 & 0.2 \\
\hline Regional number of preferential treatments & $\mathbf{0}$ & $\mathbf{0}$ & $\mathbf{0}$ & 1 & $\mathbf{0}$ & $\mathbf{0}$ & $\mathbf{0}$ & $\mathbf{0}$ & $\mathbf{0}$ \\
\hline \multicolumn{10}{|l|}{ Firms in Omsk oblast } \\
\hline "Omskshina" & 0 & 0 & 0 & 0 & 3 & 3 & 1 & 1 & 0 \\
\hline "Polet" & 0 & 0 & 1 & 1 & 2 & 1 & 1 & 1 & 1 \\
\hline "Omskenergo" & 0 & 0 & 1 & 1 & 1 & 0 & 0 & 0 & 0 \\
\hline "Omsk Meat Factory" & 0 & 0 & 0 & 0 & 0 & 1 & 0 & 0 & 0 \\
\hline The other 9 firms from the region & 0 & 0 & 0 & 0 & 0 & 0 & 0 & 0 & 0 \\
\hline Regional preferential treatment concentration & 0.2 & 0.2 & 0.5 & 0.5 & 0.39 & 0.44 & 0.5 & 0.5 & 1 \\
\hline Regional number of preferential treatments & $\mathbf{0}$ & $\mathbf{0}$ & 2 & 2 & 6 & 4 & 2 & 2 & 1 \\
\hline \multicolumn{10}{|l|}{ Firms in Chelyabinsk oblast } \\
\hline "Magnitogorsk Metallurgic Plant" & 0 & 0 & 2 & 2 & 1 & 2 & 3 & 1 & 1 \\
\hline "Chelyabinsk Electrolytic Plant" & 0 & 1 & 0 & 0 & 0 & 0 & 0 & 0 & 0 \\
\hline "Chelyabinsk Metallurgic Plant" & 0 & 0 & 0 & 1 & 0 & 0 & 0 & 0 & 0 \\
\hline "Chealyabenergo" & 0 & 0 & 0 & 1 & 0 & 0 & 0 & 0 & 0 \\
\hline "Chelyabinsk Tractor Plant" & 0 & 0 & 0 & 0 & 0 & 1 & 0 & 0 & 0 \\
\hline "Uralaz" & 0 & 0 & 0 & 0 & 0 & 1 & 0 & 0 & 0 \\
\hline The other 4 firms from the region & 0 & 0 & 0 & 0 & 0 & 0 & 0 & 0 & 0 \\
\hline Regional preferential treatment concentration & 0.2 & 1 & 1 & 0.38 & 1 & 0.38 & 1 & 1 & 1 \\
\hline Regional number of preferential treatments & $\mathbf{0}$ & 1 & 2 & 4 & 1 & 4 & 3 & 1 & 1 \\
\hline
\end{tabular}

Note: We assume that the situation when none of the firms receive any preferential treatments is equivalent to having all firms receiving the same (positive) number of preferential treatments, thus, preferential treatment concentration in this case is equal $0.2=5 *(1 / 5)^{2}$. 
Table A2. Index of regulatory capture: residual average preferential treatment concentration after accounting for number of

\begin{tabular}{|c|c|c|c|c|c|}
\hline Region & Index & Region & Index & Region & Index \\
\hline Arkhangelsk oblast & -0.306 & Samara oblast & -0.046 & Mordovia republic & 0.042 \\
\hline Irkutsk oblast & -0.306 & Karelia republic & -0.032 & Krasnodar krai & 0.053 \\
\hline Kamchatka oblast & -0.236 & Chita oblast & -0.026 & Altai republic & 0.053 \\
\hline Chuvash republic & -0.195 & Altai krai & -0.026 & Sakha (Yakutia) republic & 0.058 \\
\hline St. Petersburg city & -0.195 & Saratov oblast & -0.015 & Stavropol krai & 0.064 \\
\hline Karachaevo-Cherkess rep. & -0.167 & Kaliningrad oblast & -0.013 & Tyumen oblast & 0.069 \\
\hline Ryazan oblast & -0.167 & Nizhny Novgorod oblast & -0.006 & Moscow city & 0.073 \\
\hline Oryol oblast & -0.154 & Sverdlovsk oblast & -0.005 & Kirov oblast & 0.079 \\
\hline Novosibirsk oblast & -0.15 & Adygeya republic & -0.003 & Bryansk oblast & 0.093 \\
\hline Kaluga oblast & -0.141 & Kemerovo oblast & -0.002 & Vladimir oblast & 0.122 \\
\hline Khanty-Mansi AO & -0.141 & Lipetsk oblast & -0.002 & Vologda oblast & 0.134 \\
\hline Tambov oblast & -0.137 & Tver oblast & -0.002 & Omsk oblast & 0.135 \\
\hline Ulyanovsk oblast & -0.126 & Bashkortostan republic & 0 & Kabardino-Balkar republic & 0.137 \\
\hline Ivanovo oblast & -0.125 & Perm oblast & 0.001 & Tomsk oblast & 0.14 \\
\hline Sakhalin oblast & -0.12 & Kostroma oblast & 0.002 & Kursk oblast & 0.163 \\
\hline Yaroslavl oblast & -0.114 & Dagestan republic & 0.01 & Orenburg oblast & 0.178 \\
\hline Astrakhan oblast & -0.101 & Rostov oblast & 0.012 & Kurgan oblast & 0.189 \\
\hline Smolensk oblast & -0.098 & Volgograd oblast & 0.016 & Magadan oblast & 0.189 \\
\hline Khabarovsk krai & -0.097 & Mari-El republic & 0.024 & Murmansk oblast & 0.189 \\
\hline Voronezh oblast & -0.088 & Khakasia republic & 0.024 & Tatarstan republic & 0.213 \\
\hline Belgorod oblast & -0.087 & Krasnoyarsk krai & 0.024 & Udmurtia Republic & 0.258 \\
\hline Primorskii krai & -0.071 & Amur oblast & 0.036 & Komi republic & 0.403 \\
\hline Novgorod oblast & -0.071 & Penza oblast & 0.037 & Chelyabinsk oblast & 0.416 \\
\hline Pskov oblast & -0.071 & Moskow oblast & 0.039 & & \\
\hline Evrei autonomous oblast & -0.071 & Tula oblast & 0.042 & & \\
\hline
\end{tabular}




\section{References:}

Alesina, Alberto and Dani Rodrik.1994. "Distributive Politics and Economic Growth,” 109 Quarterly Journal of Economics 465-490.

Alt, James, Frederik Carlsen, Per Heum, and Kare Johansen. 1999. “Asset Specificity and the Political Behavior of Firms: Lobbying for Subsidies in Norway,” 53(1) International Organization 99-116.

Baldwin, Robert E. 1982. “The Political Economy of Protectionism,” in J.N. Bhagwati and T.N. Srinivasan, eds., Import Competition and Response. Chicago: University of Chicago Press.

Bardhan, Pranab and Dilip Mookherjee. 1999. "Relative Capture of Local and Central Governments. An Essay in the Political Economy of Decentralization,” CIDER Working Paper C99-109.

Barro, Robert J. 1997. Determinants of Economic Growth: Cross-Country Empirical Study. Cambridge, Mass: The MIT Press.

Barro, Robert J. and Xavier Sala-i-Martin. 1995. Economic Growth. A Graduate Textbook on Economic Growth. McGraw Hill.

Becker, Gary S. 1983. “A Theory of Competition among Pressure Groups for Political Influence,” 98 Quarterly Journal of Economics 371-400.

Bennedsen, Morten. 2000. “Political Ownership,” 76(3) Journal of Public Economics 559-581.

Blanchard, Olivier and Andrei Shleifer. 2001. "Federalism With and Without Political Centralization. China Versus Russia,” 48 IMF Staff Working Papers, Special Issue 171-179.

Boycko, Maxim, Andrei Shleifer, and Robert Vishny. 1996. “A Theory of Privatization,” 6(435) The Economic Journal 309-319. 
Brown, J. David and John S. Earle. 2000. “Competition and Firm Performance: Lessons from Russia,” SITE Working Paper No. 154.

Cai, Hongbin and Daniel Treisman. 2004. "State Corroding Federalism," Journal of Public Economics, forthcoming.

CEFIR Monitoring report. 2002. Monitoring Administrative Barriers to Small Business in Russia, Round 1, CEFIR Policy Paper.

Cook, Dennis R. 1977. “Detection of Influential Observations in Linear Inference,” 37 Journal of Statistical Planning and Inference 51-68.

Corden, Max, W. 1974. Trade Policy and Economic Welfare. Oxford: Clarendon Press.

Ericson, Richard, E. 2000. “The Post Soviet Russian Economic System: An Industrial Feudalism?” in Tuomas Komulainen and Iikka Korhonen, eds., Russian Crisis and its Effects. Helsinki: Kikimora Publications.

Friebel, Guido and Sergei Guriev. 2002. “Should I Stay or Can I Go? Worker Attachment in Russia,” CEFIR Working Paper No. 8

Frye, Timothy and Ekaterina Zhuravskaya. 2000. “Rackets, Regulations and Public Goods,” 16 Journal of Law, Economics, and Organization 478-502.

Frye, Timothy. 2002. “Capture or Exchange? Business Lobbying in Russia,” 54 (7) Europe-Asia Studies 1017-1036.

Gehlbach, Scott. 2003. “Taxability, Elections, and Government Support of Business Activity," CEFIR Working Paper No. 31.

Glaeser, Edward, Jose Scheinkman, and Andrei Shleifer. 2003. “The Injustice of Inequality,” 50(1) Journal of Monetary Economics: Carnegie-Rochester Series on Public Policy 199-222. 
Goldberg, Pinelopi, K. and Giovanni Maggi. 1999. "Protection for Sale: An Empirical Investigation,” 89(5) American Economic Review 1135-1155.

Gray, Peter, H. 1973. “Senile Industry Protection: A Proposal,” 40 Southern Economic Journal 569-74.

Gray, Peter, H. 1975. “Senile Industry Protection: Reply,” 41 Southern Economic Journal 538-41.

Grossman, Gene and Elhanan Helpman. 2001. Special Interest Politics. MIT Press, Cambridge.

Grossman, Gene and Elhanan Helpman.1994. "Protection for Sale,” 84 American Economic Review 833-50.

Guriev, Sergei and Andrei Rachinsky 2004. “Oligarchs: the Past or the Future of Russian Capitalism?” mimeo, CEFIR.

Hellman, Joel S. 1998. "Winners Take All: The Politics of Partial Reform in Postcommunist Nations,” 50(2) World Politics 203-234.

Hellman, Joel S. and Daniel Kaufmann. 2003. “The Inequality of Influence,” mimeo, the World Bank.

Hellman, Joel S. and Mark Schankerman. 2000. “Intervention, Corruption and Capture,” 8(3) Economics of Transition 545-576.

Hellman, Joel S., Geraint Jones and Daniel Kaufmann. 2003. "Seize the State, Seize the Day: State Capture, Corruption and Influence in Transition,” 31(4) Journal of Comparative Economics 751773.

Hellman, Joel S., Geraint Jones, Daniel Kaufmann and Mark Schankerman. 2000. “Measuring Governance, Corruption, and State Capture: How Firms and Bureaucrats Shape the Business Environment in Transition Economies,” World Bank Policy Research Working Paper No.2312. 
Johnson, Simon, Daniel Kaufmann, and Andrei Shleifer. 1997. “The Unofficial Economy in Transition,” 2 Brookings Papers on Economic Activity 159-239.

Laffont, Jean-Jacques and Jean Tirole. 1991. “The Politics of Government Decision-Making: A Theory of Regulatory Capture,” 106 Quarterly Journal of Economics 1089-127.

Lambert-Mogiliansky, Ariane, Konstantin Sonin, and Ekaterina Zhuravskaya. 2003. “Capture of Bankruptcy: Theory and Russian Evidence.” CEFIR Working paper No 9.

Lewis, Arthur W. 1945 “Competition in Retail Trade,” 12(48) Economica, New Series 202-234.

McMillan, John and Christopher Woodruff. 2002. “The Central Role of Entrepreneurs in Transition Economies,” 16(3) Journal of Economic Perspectives 153-170.

Mueller, Dennis C. 1989. Public Choice II: A Revised Edition of Public Choice. Cambridge: Cambridge University Press.

Murphy, Kevin M., Andrei Shleifer, and Robert W. Vishny. 1993. "Why is Rent-Seeking So Costly to Growth?” 83 (2) American Economic Review 409-414.

OECD. 2000. OECD Economic Surveys 1999-2000: The Russian Federation. Paris, OECD.

Olson, Mancur. 1965. The Logic of Collective Action. Cambridge, MA: Harvard University Press.

Olson, Mancur. 1982. The Rise and Decline of Nations: Economic Growth, Stagflation, and Social Rigidities. Yale University Press.

Parente, Stephen and Edward Prescott. 1999. “Monopoly Rights: A Barrier to Riches,” 89(5) The American Economic Review 1216-1233.

Pelzman, Sam. 1976. “Toward a More General Theory of Regulation,” 9 Journal of Law and Economics 211-40. 
Persson, Torsten and Guido Tabellini. 2000. Political Economics: Explaining Economic Policy. Cambridge: MIT Press.

Ponomareva, Maria and Ekaterina Zhuravskaya. 2004. "Federal Tax Arrears in Russia: Liquidity Problems, Federal Redistribution, or Regional Resistance?” 12(2) Economics of Transition, forthcoming.

Sala-i-Martin, Xavier. 1997. “Empirics of Economics Growth: Cross- Sectional Analysis,” 1(1) Zagreb Journal of Economics 103-132.

Shleifer Andrei and Daniel S. Treisman. 2000. Without a Map: Political Tactics and Economic Reform in Russia. Cambridge, MA: The MIT Press.

Shleifer, Andrei and Robert Vishny. 1994. "Politicians and firms," 109(4) Quarterly Journal of Economics 995-1025.

Sonin, Konstantin. 2003a. "Provincial Protectionism,” mimeo, CEFIR.

Sonin, Konstantin. 2003b. “Why the Rich May Favor Poor Protection of Property Rights?” 31(4) Journal of Comparative Economics 715-731.

Stigler, George J. 1971. “The Economic Theory of Regulation,” II Bell Journal of Economics and Management Science 3-21.

Tanguay, Georges A., Paul Lanoie and Jerome Moreau. 2004. “Environmental Policies, Public Interest and the Political Market,” Public Choice, forthcoming.

Zhuravskaya, Ekaterina. 2000. “Incentives to Provide Public Goods: Fiscal Federalism, Russian Style,” 76 (3) Journal of Public Economics 337-368. 
${ }^{\nabla}$ We are especially grateful to Andrei Shleifer for many helpful suggestions. We thank Akhmed Akhmedov, Erik Berglof, Marianne Bertrand, Scott Gehlbach, Sergei Guriev, Joel Hellman, Stanislav Kolenikov, Eric Maskin, Janos Kornai, Rory MacFarquhar, Gerard Roland, Per Stromberg, and Luigi Zingales; seminar participants at the Graduate School of Business at in the University of Chicago, the Institute for Advanced Study in Princeton, and CEFIR; and participants of the 2001 NES research conference, the "Honesty and Trust" 2002 workshop in Budapest, and the CEPR/WDI 2003 Transition Conference for useful comments. Part of the work on this paper took place when Ekaterina Zhuravskaya was on leave at the Institute for Advanced Study in Princeton. The hospitality and congenial environment of the Institute are gratefully acknowledged.

${ }^{ \pm}$Authors are at the Stockholm School of Economics; Center for Economic and Financial Research in Moscow (CEFIR); and CEFIR and CEPR, respectively.

${ }^{1}$ See Olson (1965, 1982), Stigler (1971), Pelzman (1976), Becker (1983), Laffont and Tirole (1991), Grossman and Helpman (1994, 2001), Persson and Tabellini (2000), Bardhan and Mookherjee (1999), Parente and Prescott (1999), Blanchard and Shleifer (2001), and Glaeser, Scheinkman, and Shleifer (2003).

${ }^{2}$ Murphy, Shleifer, and Vishny (1993) generalize and formalize these arguments.

${ }^{3}$ There is extensive survey evidence from transition countries that shows high cross-country variation in capture (see, for instance, Hellman, Jones, Kaufmann, and Schankerman 2000; Hellman and Schankerman 2000; Hellman, Jones, and Kaufmann 2003; Hellman and Kaufmann 2003; and Frye 2002). Empirical studies of special interest politics in developed countries are relatively scarce, with the exception of the vast literature on campaign contributions in the U.S. (surveyed in Mueller 1989). The main reason for this scarcity is the difficulty of finding direct evidence of capture. Stigler's seminal paper (1971) initiated the empirical literature by providing evidence of capture of occupation licensing in the US. Examples of recent work include Goldberg and Maggi (1999) on U.S. trade regulations; Tanguay, Lanoie, and Moreau (2004) on environmental regulations in OECD countries; and Alt, Carlsen, Heum, and Johansen (1999) on government subsidies in Norway.

${ }^{4}$ Henceforth, regulatory capture refers to capture of both the legislature and regulatory agencies.

${ }^{5}$ See, for instance, the following media sources: “Vedomosti” April 4, 2000; “Orenburg News” November 11, 2002; “Izvestiya” November 15, 2001; and “Interfax” Novermber 15, 2001.

${ }^{6}$ McMillan and Woodruff (2002) survey the evidence that new jobs in transition economies come from the small business sector. 
${ }^{7}$ Regional protection from paying federal taxes has been studied by Ponomareva and Zhuravskaya (2004); Cai and Treisman (2004); Lambert-Mogiliansky, Sonin, and Zhuravskaya (2003); and Sonin (2003a).

${ }^{8}$ As a baseline we do not distinguish between state-owned and private large firms because survey evidence (see, for instance, Frye 2002) shows that in Russia state-owned firms are engaged in state capture as much as private firms. Since the state does not have close control over state-owned firms, the managers of state-owned firms appropriate both control and cash flows for their private benefit. As a robustness check we repeated all of the analysis for just the five largest non-state firms in each region. The results are qualitatively the same irrespective of whether we base our measures of capture and political power on data for both state and non-state firms or for non-state firms only.

${ }^{9}$ Each of the 73 regions issued at least one preferential treatment between 1992 and 2000. The number of regions that granted preferential treatments and the average number of preferential treatments granted by a region were steadily increasing during 1992-1999, and decreased following Putin’s centralization by a third of the initial increase.

${ }^{10}$ Most regional economies are very concentrated; and preferential treatments are given to the largest firms: on average, the largest firm in a region produces $43 \%$ and the fifth largest firm produces $8 \%$ of the consolidated output of the five largest firms in the region; the largest firm's output is twice as large as the output of the second largest firm and three times as large as the output of the third largest. On average, the five largest firms together produce $50 \%$ of total regional output (SE is $0.6 \%$ ).

${ }^{11}$ For example, in 1996 in Omsk oblast, the firm “Omskshina” received three preferential treatments, the firm "Polet” received two, and “Omskenergo" received one preferential treatment. Thus, the shares of preferential treatments for “Omskshina,” "Polet,” and “Omskenergo” were 0.5, 0.33, and 0.17, respectively; the concentration of preferential treatments was $0.39=(0.5)^{2}+(0.33)^{2}+(0.17)^{2}$; and the number of preferential treatments was $6=3+2+1$. (Overall there are thirteen firms from Omsk oblast in our sample.)

${ }^{12}$ Preferential treatment data have the following significant drawbacks: First, we cannot compare the importance of different preferential treatments (i.e., we cannot quantify the value a tax break or the transfer of a large piece of land to a firm for free); thus, we just count the number of legislative acts with preferential treatments. Second, we can identify preferential treatment only when texts of the law contain direct reference to a firm. An example of a preferential treatment that cannot be systematically accounted for and, thus, is excluded from the data, comes from the legislation of Briansk Oblast. The 1997 law “On the regulation of the alcohol market” stated that alcohol is to be sold only by accredited firms. Any firm could get accreditation from the regional administration if it satisfied a list of criteria (for instance, by being present in the market for several years, having a storage facility of a certain size, etc.). Products sold 
by firms without accreditation were subject to confiscation. There were many firms in the market at that time, but only one firm satisfied the criteria outlined in the law. Despite these drawbacks, our measures of regional-level capture and firms’ political influence survive a number of reality checks that we discuss below when talk about a possible alternative explanation of the results.

${ }^{13}$ Initial years are different for different dependent variables because of data availability. Data on employment, profitability, sales, labor productivity, and fixed capital are available for 1992-2000; data on wage, trade, and tax arrears are available for 1996-2000. Whenever profits are below zero, log profitability is defined as -log(-profitability).

${ }^{14}$ In the fixed-effects regressions, we smooth the $P T$ _share variable over two years (the current and the previous) to minimize its volatility. Without taking this average, the power of the instrument (described below) is too low.

${ }^{15}$ In the IV fixed-effects regressions, relative employment is a proxy for size. To increase the power of this instrument, we have to limit the sample to observations in regions and years for which the total number of regional preferential treatments is greater than zero, as only in this case is initial relative employment highly correlated with the share of preferential treatments. In the case where the regional number of preferential treatments is zero, the share of preferential treatments is constant across firms while size varies. In the IV between-effects regressions, we take the relative size of capital as a proxy for size, as it has the best explanatory power for preferential treatments. One exception is the regression with fixed capital as dependent variable, where this instrument is collinear with the initial level of the dependent variable in the first-stage regression; in that case we instrument with relative initial employment. Henceforth, F-statistics for the instruments from the first-stage regressions are reported for each regression in the bottom row of the tables with results.

${ }^{16}$ In the firm-level fixed-effects regressions $P T \_$concentr and $P T \_n u m b e r$ are very highly correlated; thus, we orthogonalize them before including them in the regression. An alternative approach of including just $P T$ _concentr (without controlling for $P T \_n u m b e r$ ) leads to the same results. We use lags because we do not have appropriate instruments for these two variables in this specification.

${ }^{17}$ To improve the quality of instruments, we use data between 1996 and 2000 for over-time averages and take the log of preferential treatment concentration. The logarithm of preferential treatment concentration is instrumented by the concentration of the sum of preferential treatments that firms received between 1992 and 1995 . The number of preferential treatments is instrumented by the total number of preferential treatments issued by the region to the five largest recipients of preferential treatments between 1992 and 1995. 
${ }^{18}$ A one standard deviation increase in log average preferential treatment concentration from the mean implies that, in four out of five years, the number of preferential treatments for each of the five largest recipients remains unchanged: the largest recipient gets two preferential treatments, another two enterprises receive one each and no other firm receives preferential treatments; but in the fifth year, only one firm receives four preferential treatments.

${ }^{19}$ Retail turnover is used as an indirect proxy because reporting on retail turnover is often much better than on smallbusiness employment: many small firms underreport employment for tax evasion purposes. Thus, retail turnover is less susceptible to the size of the unofficial economy, which can be related to regulatory environment. See Johnson, Kaufmann, and Shleifer (1997) for theory and cross-country evidence and Frye and Zhuravskaya (2000) for enterprisesurvey evidence.

${ }^{20}$ Controls are motivated by the growth literature. See, for instance, Barro 1997, Barro and Sala-i-Martin 1995, and Sala-i-Martin 1997. Life expectancy was excluded from the list of controls because it has insufficient variation across regions. Wage level is instrumented by its initial level to avoid endogeneity.

${ }^{21}$ The initial preferential treatment concentration is constructed as the average PT_concentr for the initial three years $\left(\mathrm{t}_{0}\right.$, $t_{-1}$, and $t_{-2}$ ). The initial year for each dependent variable is defined as follows: retail turnover per capita - 1995; share of small business employment - 1997; GRP per capita - 1994. The last year for which the data are available is 2000. ${ }^{22}$ A one standard deviation increase in the average regional preferential treatment concentration from the mean implies that, in five out of six years, the number of preferential treatments for each of the five largest recipients remains unchanged: the largest recipient gets two preferential treatments, another two enterprises receive one each and no other firm receives preferential treatments; but in the sixth year, only one firm receives four preferential treatments.

${ }^{23}$ The exact specification is as follows:

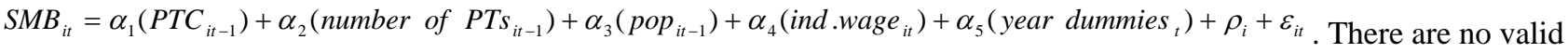
instruments for $P T \_c o n c e n t r$ and $P T \_n u m b e r ;$ thus, we take one-year lags. Following the growth literature, we do not test for the relationship between the short-run changes in capture and per- capita GRP because short-run changes in GRP are primarily driven by business cycles.

${ }^{24} \mathrm{~A}$ one standard deviation increase in preferential treatment concentration from the mean value implies that among the five largest recipients of preferential treatments in one year, the distribution of the number of preferential treatments changes from $\{2 ; 1 ; 1 ; 0 ; 0\}$ to $\{3,1,0 ; 0 ; 0\}$. 
${ }^{25}$ It is worth noting that it is very important to control for the number of preferential treatments in these regressions since the relationship between the number of preferential treatments and taxes is purely mechanical: preferential treatments cost money.

${ }^{26}$ The capture of legislatures and regulatory agencies reflected in preferential treatment concentration is an indication of merely one aspect of a broader phenomenon of institutional subversion. In particular, the political influence of vested interests extends to law enforcement. To check the robustness of our results, we take output concentration among the ten largest non-state firms in each region as a measure of regional potential capture. The rationale behind this measure is that bigger agents organize interests more easily (Grossman and Helpman 2001; Sonin 2003a; Glaeser, Scheinkman, and Shleifer 2003). We find that a one standard deviation increase in the output concentration among the ten largest firms (from a mean value of 0.226 ) leads to a decrease in the share of small business employment of $23 \%$ and in regional tax collection of $6.1 \%$, all else equal.

${ }^{27}$ This variable is available for 39 regions in 2001. All TI and INDEM data, along with their description, can be found at http://www.anti-corr.ru/rating_regions/index.htm.

${ }^{28}$ This index is available for 72 regions in 1999 and 2000. The data and construction methodology can be found at www.freepress.ru. 